\title{
Kemandirian belajar dan kedisipilinan belajar terhadap prestasi mahasiswa pada perkuliahan daring
}

\author{
Rahmat Winata ${ }^{1}$, Rizki Nurhana Friantini ${ }^{2}$, Robia Astuti ${ }^{3}$ \\ 1,2STKIP Pamane Talino, ${ }^{3}$ Universitas Muhammadiyah Pringsewu \\ e-mail: rnfriantini@gmail.com
}

\begin{abstract}
Abstrak
Tujuan dari penelitian ini adalah untuk mengetahui 1) pengaruh kemandirian belajar terhadap prestasi belajar matematika, 2) pengaruh kedisiplinan belajar terhadap prestasi belajar matematika, dan 3) pengaruh kemandirian belajar dan kedisiplinan belajar secara bersama-sama terhadap prestasi belajar matematika pada perkuliahan daring untuk mata kuliah Pengantar Dasar Matematika mahasiswa semester 1 Program Studi Pendidikan Matematika STKIP Pamane Talino. Jenis penelitian adalah kuantitatif menggunakan pendekatan ex post facto. Populasi penelitian ini adalah mahasiswa semester 1 Program Studi Pendidikan Matematika yang berjumlah 37 orang. Teknik analisis data dengan menggunakan regresi linier ganda yang sebelumnya diuji prasyarat menggunakan uji normalitas menggunakan kolmogorov-smirnov, uji heteroskedastisitas dengan metode Glejser, outokorelasi dengan metode Durbin-Watson, multikolinieritas dengan menggunakan metode Tolerance (TOL) dan Variance Inflation Factor (VIF), dan linieritas menggunakan metode Lagrange Multiplier. Dari penelitian diketahui bahwa 1) Terdapat pengaruh kemandirian belajar terhadap prestasi belajar matematika, 2) Terdapat pengaruh kedisiplinan belajar terhadap prestasi belajar matematika, 3) Terdapat pengaruh kemandirian belajar dan kedisiplinan belajar secara bersamasama terhadap prestasi belajar matematika pada perkuliahan daring untuk mata kuliah Pengantar Dasar Matematika mahasiswa semester 1 Program Studi Pendidikan Matematika STKIP Pamane Talino. Dari hasil R Square = 0,422 x $100 \%$ $=42,2 \%$ yang menunjukkan bahwa prestasi belajar matematika mahasiswa semester 1 pada mata kuliah Pengantar Dasar Matematika dapat dijelaskan oleh kemandirian belajar dan kedisiplinan sebesar $42,2 \%$
\end{abstract}

Kata kunci: kemandirian belajar, kedisiplinan belajar, prestasi, perkuliahan daring

Open Access This is an open access article distributed under the terms of the Creative Commons Attribution 4.0 International License

Website: http://ejournal.umpri.ac.id/index.php/e-DuMath

\section{PENDAHULUAN}

Pada masa LFH (Learn From Home) dikarenakan adanya pandemi Covid-19 yang masih berlangsung hingga saat ini, tentunya memberikan efek tersendiri bagi pelaksanaan perkuliahan. Efek tersebut dirasakan tidak hanya dosen atau pengajar saja tetapi lebih utama dirasakan pada mahasiswa. Apalagi perkuliahan yang selama ini selalu identik dengan tatap muka, secara mendadak berganti menjadi perkuliahan daring. Melalui pembelajaran daring, dosen menjadi harus mengubah gaya mengajar konvensional yang secara tidak langsung mempengaruhi profesionalitas kerja (Anim \& 
Mapilindo, 2020) sedangkan mahasiswa menjadi tidak dituntut untuk datang ke kelas, tetapi bisa mengakses pembelajaran melalui internet karena kegiatan pembelajaran memanfaatkan jaringan sebagai metode penyampaian, interaksi, dan fasilitas (Anugrahana, 2020).

Pelaksanaan perkuliahan daring semacam ini pasti memberikan efek khususnya bagi mahasiswa yang tidak cepat beradaptasi dengan kondisi perkuliahan saat ini. Dari hasil penelitian diperoleh bahwa banyak kesulitan dalam melaksanakan pembelajaran daring karena pembelajaran daring lebih menuntut mahasiswa agar bersifat aktif dan kritis dalam mempelajari topik yang dikaji dalam perkuliahan dibandingkan dengan saat tatap muka (Badjeber, 2020). Selain itu dengan pembelajaran daring menjadi sulit untuk berkomunikasi dengan pengajar, dan merasa terbebani karena tugas yang menumpuk, serta sulitnya memahami materi yang diberikan (Puspaningtyas \& Dewi, 2020).

Pada perkuliahan daring seperti sekarang ini tentunya sikap kemandirian belajar sangat penting sekali untuk dimiliki mahasiswa. Hal ini dikarenakan pada perkuliahan daring mahasiswa dituntut untuk belajar dan memahami materi sendiri serta mencari sumber belajar lain yang relevan dengan materi perkuliahan secara mandiri (Friantini \& Winata, 2020). Pada perkuliahan daring, dosen tidak lagi mejadi tokoh utama yang berperan penting dalam pengajaran tetapi justru mahasiswa yang harus aktif untuk belajar secara mandiri dan mengeksplorasi kemampuannya dalam kegiatan belajar (Sobri et al., 2020). Oleh karena itu kemandirian belajar mahasiswa sangat dituntut untuk dapat mencapai keberhasilan belajarnya.

Kemandirian belajar merupakan cara belajar yang aktif secara individu untuk mencapai tujuan akademik yang ditargetkan dengan mengontrol perilaku, memotivasi diri sendiri, dan menggunakan kognitifnya untuk belajar (Wahyuni \& Nurhayati, 2019). Seseorang yang mempunyai kemandirian belajar berarti ia mempunyai keinginan sendiri untuk belajar, dapat memotivasi dirinya untuk belajar, menyelesaikan masalah belajarnya, serta bertanggung jawab untuk menyelesaikan kewajiban belajarnya. Sedangkan seorang mahasiswa yang mandiri secara belajar maka ia terlibat aktif untuk memaksimalkan kesempatan saat pembelajaran, aktif untuk mengontrol sendiri segala yang ia kerjakan, mengevaluasi dan merencanakan sesuatu yang lebih dalam pembelajaran serta mau untuk aktif dalam proses pembelajaran (Badjeber, 2020).

Kemandirian belajar merupakan faktor yang penting dalam pembelajaran daring karena adanya kesadaran untuk belajar dengan tidak bergantung pada orang lain dan bertanggung jawab dalam mencapai tujuan yang diinginkan (Yuliati \& Saputra, 2020). Seseorang memiliki kemandirian belajar yang tinggi, ia tidak akan bergantung pada orang lain ketika belajar dan berinisiatif sendiri untuk mencari sumber-sumber belajar yang relevan untuk dipelajari sehingga kualitas pembelajarannya menjadi lebih baik (Aulia \& Armiati, 2019). Apabila mahasiswa mempunyai kemandirian belajar yang tinggi pada perkuliahan daring saat ini, pasti tugas-tugas belajar yang banyak tidak membuat mereka menjadi terbebani tetapi membuat mereka termotivasi untuk mempelajari dan menyelesaikannya dan dengan tugas tersebut mahasiswa menjadi dapat lebih memahami mengenai materi yang sedang diajarkan.

Kemandirian belajar merupakan salah satu faktor yang mempengaruhi prestasi belajar. Kemandirian belajar merupakan faktor penting yang menjadi penentu keberhasilan mahasiswa dalam proses perkuliahan yang dilakukannya (Sudiana et al., 2017). Kemandirian belajar juga merupakan faktor yang dapat meningkatkan prestasi akademik karena dengan kemandirian belajar dapat mengatur dan memantau belajarnya secara efektif, mengatur waktu untuk menyelesaikan tugasnya, serta memperoleh skor yang lebih tinggi pada pembelajaran sains (Octaria et al., 2020).

Selain kemandirian belajar, faktor lain yang penting untuk dimiliki mahasiswa pada perkuliahan daring adalah kedisiplinan belajar. Hal ini dikarenakan dengan 
disiplin belajar, suasana belajar yang kondusif dan optimal dapat diwujudkan (Purwaningsih, 2020). Tentunya suasana belajar yang kondusif dan optimal sangat diperlukan agar perkuliahan daring saat ini dapat dilaksanakan dengan maksimal dan mencapai hasil yang diinginkan. Kedisiplinan belajar merupakan sikap pengendalian diri dalam bentuk aturan baik tertulis maupun tidak tertulis yang diterapkan sebagai bentuk kesadaran dan tanggung jawab untuk belajar (Supardi, 2014).

Menurut (Rusydayana \& Supriyanto, 2013) mahasiswa yang mempunyai sikap kedisiplinan dalam belajar kemungkinan besar akan menerapkan kesehariannya dengan tidak menyimpang dari peraturan dan kewajiban yang dibebankan kepadanya. Dengan mahasiswa memiliki sikap kedisiplinan belajar, mahasiswa berkomitmen untuk tetap belajar sesuai waktu kuliah selayaknya perkuliahan tatap muka dan tetap melaksanakan tugas belajar yang diberikan. Hal ini dikarenakan dengan memiliki kedisiplinan belajar akan mendidik untuk menyukai peraturan-peraturan atau jadwal yang sudah ditetapkan sehingga mencapai hasil yang memuaskan dan juga dapat memotivasi untuk mencapai cita-cita yang diinginkan (Wirantasa, 2017).

Melalui sikap kedisiplinan belajar yang dimiliki mahasiswa juga dapat menjamin pencapaian prestasi belajar yang maksimal karena disiplin merupakan salah satu faktor yang mempengaruhi hasil belajar (Rusydayana \& Supriyanto, 2013) dan salah satu kunci untuk mencapai keberhasilan dan kesuksesan dalam belajar (Anas \& Fitriani, 2019). Oleh karenanya kedisiplinan belajar perlu ditanamkan sejak dini karena pengaruh kedisiplinan belajar sangat besar terhadap prestasi (Anugrahana, 2020). Hal ini dibuktikan dengan hasil penelitian (Wirantasa, 2017) yang menyimpulkan bahwa kedisiplinan belajar mempengaruhi prestasi belajar, sehingga semakin tinggi kedisiplinan belajar maka semakin tinggi juga prestasi belajar yang dicapai, serta kedisiplinan belajar sangat mendukung dalam pencapaian prestasi belajar khususnya pada bidang matematika.

Oleh karena kedua aspek ini, yaitu kemandirian belajar dan kedisiplinan belajar merupakan aspek yang menjadi faktor penting dari prestasi belajar maka pada penelitian ini akan dilihat 1) pengaruh kemandirian belajar terhadap prestasi mahasiswa pada perkuliahan daring, 2) pengaruh kedisiplinan belajar terhadap prestasi mahasiswa pada perkuliahan daring, dan 3) pengaruh kemandirian belajar dan kedisiplinan belajar secara bersama-sama terhadap prestasi mahasiswa pada perkuliahan daring. Prestasi mahasiswa pada perkuliahan daring yang dilihat khususnya pada mata kuliah Pengantar Dasar Matematika.

\section{METODE}

Jenis penelitian ini adalah penelitian kuantitatif dengan pendekatan ex post facto. Penelitian ini dilaksanakan di STKIP Pamane Talino pada semester ganjil tahun akademik 2020/2021. Populasi penelitian adalah 37 mahasiswa semester 1 Program Studi Pendidikan Matematika STKIP Pamane Talino yang mengikuti perkuliahan daring untuk mata kuliah Pengantar Dasar Matematika. Teknik pengambilan sampel menggunakan sampel jenuh. Metode pengumpulan data menggunakan metode tes dan angket. Untuk angket kemandirian belajar menggunakan indikator yaitu: 1) Percaya diri, 2) Disiplin, 3) Inisiatif, 4) Tanggung jawab, dan 5) Motivasi (Friantini \& Winata, 2020) sedangkan angket kedisiplinan belajar menggunakan indikator yaitu: 1) Dapat mengatur waktu, 2) Rajin dan teratur belajar, 3) Perhatian untuk belajar, 4) Ketertiban diri (Tu'u, 2008).

Teknik analisis data menggunakan analisis regresi yaitu analisis regresi linier ganda. Tujuan analisis regresi ialah menentukan model statistik yang dapat dipakai 
untuk memprediksi nilai-nilai variabel terikat berdasarkan nilai-nilai dari variabel bebas (Budiyono, 2009). Sebelum dianalisis menggunakan regresi dilakukan uji prasyarat yaitu uji normalitas menggunakan kolmogorov-smirnov, uji heteroskedastisitas dengan metode Glejser, outokorelasi dengan metode Durbin-Watson, multikolinieritas dengan menggunakan metode Tolerance (TOL) dan Variance Inflation Factor (VIF), dan linearitas menggunakan metode Lagrange Multiplier.

\section{HASIL DAN PEMBAHASAN}

Penelitian ini menggunakan instrumen tes prestasi dan angket ada dua jenis yaitu angket kemandirian belajar dan angket kedisiplinan belajar. Setelah diuji coba, diperoleh 5 butir soal untuk tes prestasi, 30 butir pernyataan untuk angket kemandirian belajar, dan 20 butir pernyataan untuk angket kedisiplinan belajar. Instrumen tes dan angket kemudian diberikan kepada 37 mahasiswa semester 1 tahun Program Studi Pendidikan Matematika STKIP Pamane Talino pada perkuliahan daring untuk mata kuliah Pengantar Dasar Matematika mahasiswa.

Setelah intrumen diberikan kepada mahasiswa yang mengikuti mata kuliah Pengantar Dasar Matematika dan diperoleh data tes prestasi, kemandirian belajar, dan kedisiplinan belajar, selanjutnya data tersebut dianalisis. Sebelum menggunakan analisis regresi linier ganda dilakukan uji prasyarat terlebih dahulu. Uji prasyarat yang dilakukan sebanyak 5 syarat yaitu sebagai berikut.

Untuk uji normalitas dilakukan dengan metode Kolmogorov-Smirnov berbantuan SPSS versi 17. Hipotesis untuk uji normalitas data sebagai berikut:

$\mathrm{H}_{0}$ : Data berasal dari populasi yang berdistribusi normal

$\mathrm{H}_{1}$ : Data berasal dari populasi yang berdistribusi tidak normal

Hasil uji normalitas dapat dilihat pada Tabel 1 berikut.

\section{Tabel 1. One-Sample Kolmogorov-Smirnov Test}

\begin{tabular}{llr}
\hline & & \multicolumn{2}{c}{ Standardized } \\
Residual & \\
$\mathrm{N}$ & & 37 \\
Normal Parameters & Mean &, 000000 \\
& Std. Deviation &, 97182532 \\
Most Extreme & Absolute &, 149 \\
Differences & Positive &, 149 \\
& Negative &,- 123 \\
Kolmogorov-Smirnov Z & &, 907 \\
Asymp. Sig. (2-tailed) & &, 383 \\
\hline \multicolumn{2}{c}{ a. Test distribution is Normal. b. Calculated from data. }
\end{tabular}

Kriteria pengujian hipotesisnya pada taraf signifikansi $5 \%$ atau a $=0,05$ adalah $H_{0}$ diterima jika angka signifikansi (sig) > a maka data berdistribusi normal. Dari Tabel 1 dapat dilihat bahwa nilai sig yang diperoleh dari hasil uji normalitas dengan menggunakan metode Kolmogorov-Smirnov sebesar 0,383 lebih dari 0,05 ( $\mathrm{sig}=$ 0,383 > $0,05)$ sehingga $H_{0}$ diterima. Oleh karena itu dapat disimpulkan bahwa data berasal dari populasi yang berdistribusi normal.

Untuk uji heteroskedastisitas dilakukan dengan Metode Glejser berbantuan SPSS versi 17. Hipotesis untuk uji heteroskedastisitas sebagai berikut:

$H_{0}$ :Model tidak mengandung gejala heteroskedastisitas 
$H_{1}$ :Model mengandung gejala heteroskedastisitas

Hasil uji heteroskedastisitas dapat dilihat pada Tabel 2.

\begin{tabular}{llrrrrr}
\multicolumn{8}{c}{ Tabel 2. Hasil uji heteroskedastisitas } \\
Coefficients \\
\hline Model
\end{tabular}

a. Dependent Variable: ABRESID

Dapat dilihat pada Tabel 2 bahwa nilai sig. dari kemandirian belajar 0,312 lebih besar dari 0,05 dan sig. kedisiplinan belajar 0,551 lebih besar dari 0,05 maka $H_{0}$ diterima. Hal ini berarti model regresi tidak mengandung gejala heteroskedastisitas.

Untuk uji outokorelasi dilakukan dengan metode Durbin-Watson berbantuan SPSS versi 17. Jika nilai pada tabel Durbin-Watson lebih dari $d U$ dan kurang dari $4-$ $d U$ maka tidak terdapat outokorelasi. Hasil uji outokorelasi dapat dilihat pada Tabel 3.

Tabel 3. Hasil uji outokorelasi

\begin{tabular}{cccccc}
\hline \multirow{2}{*}{ Model } & $\mathrm{R}$ & $\mathrm{R}$ & Model Summaryb $^{\mathrm{b}}$ Adjusted & Std. Error of & Durbin- \\
& & Square & R Square & the Estimate & Watson \\
1 & $.650^{\mathrm{a}}$ &, 422 &, 388 & 9,576 & 1,873 \\
\hline
\end{tabular}

a. Predictors: (Constant), Kedisiplinan_Belajar, Kemandirian_Belajar

b. Dependent Variable: Prestasi_Belajar

Dapat dilihat pada Tabel 3 bahwa nilai Durbin-Watson (d) sebesar 1,873. Untuk $d U<d<4$ - $d U$ maka $1,590<d<2,410$, sedangkan nilai $d=1,873$ sehingga $d$ terletak diantara $d U$ dan $4-D u(1,590<d=1,873<2,410)$. Dapat disimpulkan model persamaan regresi tidak terdapat outokorelasi.

Untuk uji multikolinieritas dengan menggunakan metode Tolerance (TOL) dan Variance Inflation Factor (VIF) berbantuan SPSS. Jika nilai VIF $<10$ maka tidak terdapat gejala multikolinieritas. Hasil uji multikolinieritas dapat dilihat pada Tabel 4 .

Tabel 4. Hasil uji multikolinieritas

\begin{tabular}{|c|c|c|c|c|c|c|c|c|}
\hline \multicolumn{9}{|c|}{ Coefficients $^{a}$} \\
\hline \multirow{2}{*}{\multicolumn{2}{|c|}{ Model }} & \multicolumn{2}{|c|}{$\begin{array}{l}\text { Unstandardized } \\
\text { Coefficients }\end{array}$} & \multirow{2}{*}{$\begin{array}{c}\text { Standardized } \\
\text { Coefficients } \\
\text { Beta }\end{array}$} & \multirow[t]{2}{*}{$\mathrm{t}$} & \multirow[t]{2}{*}{ Sig. } & \multicolumn{2}{|c|}{$\begin{array}{c}\text { Collinearity } \\
\text { Statistics }\end{array}$} \\
\hline & & B & $\begin{array}{l}\text { Std. } \\
\text { Error }\end{array}$ & & & & Tolerance & VIF \\
\hline \multirow[t]{3}{*}{1} & (Constant) & 6,428 & 15,778 & & ,407 & ,686 & & \\
\hline & Kemandirian_Belajar & 319 & ,105 & , 445 & 3,047 &, 004 & ,795 & 1,258 \\
\hline & Kedisiplinan_Belajar &, 538 & ,252 &, 313 & 2,138 &, 040 &, 795 & 1,258 \\
\hline
\end{tabular}

a. Dependent Variable: Prestasi_Belajar 
Dapat dilihat pada Tabel 4 nilai VIF (Variance Inflation Factor) sebesar 1,258. Oleh karena VIF $=1,258$ tidak lebih dari $10(\mathrm{VIF}=1,258<10)$ maka model dinyatakan tidak terdapat gejala multikolinieritas.

Untuk uji linieritas dengan menggunakan metode Lagrange Multiplier dengan hipotesis sebagai berikut:

$H_{0}$ : Model regresi linear

$H_{1}$ : Model regresi tidak linear

Hasil uji linieritas dapat dilihat pada Tabel 5.

Tabel 5. Hasil uji linieritas

\begin{tabular}{lrrrr}
\hline \multirow{4}{*}{ Model } & \multicolumn{4}{c}{ Model Summary } \\
& $\mathrm{R}$ & $\mathrm{R}$ & Adjusted & Std. Error \\
& & Square & $\mathrm{R}$ & of the \\
& & & Square & Estimate \\
1 & $.016^{\mathrm{a}}$ &, 000 &,- 059 & 9,57476644 \\
\hline
\end{tabular}

a. Predictors : (Constant), Kemandirian_Belajar_Sqr,Kedisiplinan_Sqr

Dari Tabel 5 dapat diperoleh koefisien determinasi (R Square) sebesar 0,000 sehingga $C h i$ Square $=\mathrm{R}$ Square x jumlah sampel $=0,000 \times 37=0$ sedangkan Chi Square tabel dengan $d f=(0,05 ; 37)=52,19232$. Karena Chi Square $<$ Chi Square tabel maka $H_{0}$ diterima. Hal ini berarti model regresi linear.

Dari penjelasan di atas dapat disimpulkan bahwa uji prasyarat semua telah terpenuhi. Setelah semua uji prasyarat terpenuhi selanjutnya dilakukan uji hipotesis menggunakan regresi linier ganda. Berikut hasil dari analisis regresi linier ganda.

Tabel 6. Persamaan Regresi

\begin{tabular}{|c|c|c|c|c|c|c|}
\hline \multicolumn{7}{|c|}{ Coefficients $^{a}$} \\
\hline \multirow{2}{*}{\multicolumn{2}{|c|}{ Model }} & \multicolumn{2}{|c|}{$\begin{array}{l}\text { Unstandardized } \\
\text { Coefficients }\end{array}$} & \multirow{3}{*}{$\begin{array}{c}\text { Standardized } \\
\text { Coefficients } \\
\text { Beta }\end{array}$} & \multirow[t]{2}{*}{$\mathrm{t}$} & \multirow[t]{2}{*}{ Sig. } \\
\hline & & B & $\begin{array}{l}\text { Std. } \\
\text { Error }\end{array}$ & & & \\
\hline \multirow[t]{3}{*}{1} & (Constant) & 6,428 & 15,778 & & , 407 & ,686 \\
\hline & Kemandirian_Belajar & ,319 &, 105 & ,445 & 3,047 & ,004 \\
\hline & Kedisiplinan & ,538 & , 252 & 313 & 2,138 & ,040 \\
\hline
\end{tabular}

a. Dependent Variable: Prestasi_Belajar

Berdasarkan hasil analisis dengan menggunakan SPSS 17 pada Tabel 6 diperoleh harga $b_{0}=6,428, b_{1}=0,319$ dimana $b_{1}$ merupakan koefisien dari variabel $\mathrm{X}_{1}$ (Kemandirian Belajar), dan $\mathrm{b}_{2}=0,538$ dimana $\mathrm{b}_{2}$ merupakan koefisien dari variabel $\mathrm{X}_{2}$ (Kedisiplinan Belajar) sehingga dapat disusun dalam persamaan regresi dugaan yaitu

$$
\hat{Y}=6,428+0,319 \mathrm{X}_{1}+0,538 \mathrm{X}_{2}
$$

Dari persamaan regresi di atas, harga konstanta sebesar 6,428 menyatakan bahwa jika tidak ada kemandirian belajar dan kedisiplinan belajar maka prestasi adalah 6,428. Koefisien regresi $X_{1}$ sebesar 0,319 menyatakan bahwa setiap perubahan kemandirian belajar sebesar 1 satuan maka akan meningkatkan prestasi sebesar 0,319 satuan. Koefisien regresi $X_{2}$ sebesar 0,538 menyatakan bahwa setiap perubahan kemandirian belajar sebesar 1 satuan maka akan meningkatkan prestasi sebesar 0,538 satuan.

Kemudian dari Tabel 6, sig. kemandirian belajar sebesar 0,004 lebih kecil dari 0,05 maka terdapat pengaruh kemandirian belajar terhadap prestasi mahasiswa semester 1 
Program Studi Pendidikan Matematika STKIP Pamane Talino pada perkuliahan daring untuk mata kuliah Pengantar Dasar Matematika. Hasil ini sejalan dengan penelitian Aulia \& Armiati (2019) yang memperoleh hasil bahwa kemandirian belajar berpengaruh signifikan terhadap hasil belajar. Selain itu dari hasil penelitian (Hatip \& Listiana, 2019) diperoleh hasil bahwa ada pengaruh kemandirian belajar terhadap prestasi belajar yang pada penelitian ini pembelajaran dengan menggunakan aplikasi Edmodo.

Selanjutnya dari Tabel 6, sig. kedisiplinan sebesar 0,040 lebih kecil dari 0,05 maka terdapat pengaruh kedisiplinan belajar terhadap prestasi mahasiswa semester 1 Program Studi Pendidikan Matematika STKIP Pamane Talino pada perkuliahan daring untuk mata kuliah Pengantar Dasar Matematika. Hasil ini sejalan dengan penelitian Harling (2020) yang menyimpulkan bahwa terdapat hubungan yang positif dan signifikan antara kedisiplinan belajar dan prestasi dan penelitian Puspita (2018) yang menghasilkan bahwa kedisiplinan belajar berpengaruh secara positif terhadap hasil belajar mahasiswa.

Tabel 7. ANOVA

\begin{tabular}{llrrrrr}
\hline Model & & Sum of & df & Mean & F & Sig. \\
& & Squares & & Square & & \\
\multirow{2}{*}{1} & Regression & 2278,545 & 2 & 1139,273 & 12,424 & $.000^{\text {a }}$ \\
& Residual & 3117,779 & 34 & 91,699 & & \\
& Total & 5396,324 & 36 & & & \\
\hline
\end{tabular}

a. Predictors : (Constant), Kemandirian_Belajar, Kedisiplinan

b. Dependent Variable : Prestasi_Belajar

Pada Tabel 7 terlihat sig. sebesar 0,000 lebih kecil dari 0,05 maka terdapat pengaruh kemandirian belajar dan kedisiplinan belajar secara bersama-sama terhadap prestasi mahasiswa semester 1 Program Studi Pendidikan Matematika STKIP Pamane Talino pada perkuliahan daring untuk mata kuliah Pengantar Dasar Matematika.

Tabel 8. Koefisien Determinasi

\begin{tabular}{lcccr}
\hline \multirow{3}{*}{ Model } & $\mathrm{n}$ & \multicolumn{2}{c}{ Model Summary } \\
& & $\mathrm{R}$ & Adjusted & Std. Error of \\
1 & & Square & R Square & the Estimate \\
& $.650^{\text {a }}$ &, 422 &, 388 & 9,576 \\
\hline
\end{tabular}

a. Predictors: (Constant), Kemandirian_Belajar, Kedisiplinan

Selanjutnya menghitung koefisien determinasi yaitu angka yang digunakan untuk melihat suatu ukuran seberapa tepat model regresi linear dugaan dapat menjelaskan hubungan linearnya antara variabel pada $X_{1}$ dan $X_{2}$ dengan $Y$. Berdasarkan hasil analisis dengan menggunakan program SPSS 17 pada Tabel 8, R Square $=0,422 \times 100$ $\%=42,2 \%$ yang menunjukkan bahwa mahasiswa pada perkuliahan daring mata kuliah Pengantar Dasar Matematika dapat dijelaskan oleh kemandirian belajar dan kedisiplinan belajar sebesar $42,2 \%$ sisanya $57,8 \%$ dijelaskan oleh faktor lain yang tidak diteliti dalam penelitian ini.

\section{SIMPULAN}

Berdasarkan hasil penelitian, dapat disimpulkan bahwa 1) Terdapat pengaruh kemandirian belajar terhadap prestasi mahasiswa semester 1 Program Studi Pendidikan Matematika STKIP Pamane Talino pada perkuliahan daring untuk mata kuliah Pengantar Dasar Matematika. 2) Terdapat pengaruh kedisiplinan terhadap prestasi mahasiswa semester 1 Program Studi Pendidikan Matematika STKIP Pamane Talino pada perkuliahan daring untuk mata kuliah Pengantar Dasar Matematika. 3) 
Terdapat pengaruh kemandirian belajar dan kedisiplinan belajar secara bersama-sama terhadap prestasi mahasiswa semester 1 Program Studi Pendidikan Matematika STKIP Pamane Talino pada perkuliahan daring untuk mata kuliah Pengantar Dasar Matematika. Dari hasil R Square $=0,422 \times 100 \%=42,2 \%$ yang menunjukkan bahwa prestasi mahasiswa pada perkuliahan daring untuk mata kuliah Pengantar Dasar Matematika dapat dijelaskan oleh kemandirian belajar dan kedisiplinan sebesar $42,2 \%$.

\section{REFERENSI}

Anas, A., \& Fitriani, A. (2019). Dampak Media E-Learning Terhadap Kedisiplinan Dalam Mengerjakan Tugas Dan Motivasi. Pedagogy P-ISSN: 2502-3802 e-ISSN: 2502-3799 DAMPAK, 4(1), 74-82.

Anim, \& Mapilindo. (2020). PERSEPSI MAHASISWA PENDIDIKAN MATEMATIKA TENTANG PEMBELAJARAN DARING SELAMA MASA LEARN FROM HOME (LFH) PANDEMIC COVID-19. Jurnal MATEMATICS PAEDAGOGIC, V(1), 72-80.

Anugrahana, A. (2020). Hambatan, Solusi dan Harapan : Pembelajaran Daring Selama Masa Pandemi Covid-19 Oleh Guru Sekolah Dasar. Scholaria: Jurnal Pendidikan Dan Kebudayaan, 10(3), 282-289.

Aulia, Z., \& Armiati, A. (2019). Pengaruh Kemandirian Belajar dan Persepsi Siswa Tentang Metode Mengajar Guru Terhadap Hasil Belajar Siswa Kelas X Pada Mata Pelajaran Administrasi Umum di SMK Negeri 1 Padang Panjang. Jurnal Ecogen, 2(4), 811. https://doi.org/10.24036/jmpe.v2i4.7858

Badjeber, R. (2020). Kemandirian belajar mahasiswa tadris matematika FTIK IAIN Palu selama masa pembelajaran daring. JPMI: Jurnal Pembelajaran Matematika Inovatif, 1(1), 1-9.

Budiyono. (2009). Statistika untuk Penelitian (2nd ed.). UNS Press.

Friantini, R. N., \& Winata, R. (2020). Disposisi Matematis Dan Kemandirian Belajar Mahasiswa Pada Perkuliahan Daring Berbantuan Google Classroom Masa Covid19. Jurnal Derivat: Jurnal Matematika Dan Pendidikan Matematika, 7(2), 53-64. https://doi.org/10.31316/j.derivat.v7i2.1068

Harling, V. N. Van. (2020). Analisis Hubungan Kedisiplinan Belajar Dari Rumah ( Bdr ) Dengan Prestasi Belajar Kimia Siswa Selama Masa Pandemi. SOSCIED, 3(2).

Hatip, A., \& Listiana, Y. (2019). MINAT, KEMANDIRIAN DAN HASIL BELAJAR MAHASISWA PENDIDIKAN MATEMATIKA DALAM E-LEARNING BERBASIS EDMODO. AKSIOMA: Jurnal Program Studi Pendidikan Matematika, 8(3), 485496. https://media.neliti.com/media/publications/112355-ID-pengaruh-strukturaktiva-ukuran-

perusaha.pdf\%0Acholar.google.es/scholar?hl=es\&as_sdt=0\%2C5\&q=Funcionalidad + Familiar+en+Alumnos $+\mathrm{de}+1^{\circ}+\mathrm{y}+2^{\circ}+$ grado $+\mathrm{de}+$ secundaria + de + la + institución + educa tiva+parroquial+"Peque

Octaria, D., Fitriasari, P., \& Sari, N. (2020). Blended Learning dengan Macromedia Flash untuk Melatih Kemandirian Belajar Mahasiswa. Jurnal Elemen, 6(1), 25-38. https://doi.org/10.29408/jel.v6i1.1596

Purwaningsih, D. (2020). PENGARUH KEDISIPLINAN BELAJAR DAN INTENSITAS BELAJAR TERHADAP KEMAMPUAN PEMAHAMAN KONSEP MATEMATIS Dian Purwaningsih. JURNAL DIALEKTIKA, 10(1), 347-352.

Puspaningtyas, N. D., \& Dewi, P. S. (2020). PERSEPSI PESERTA DIDIK TERHADAP PEMBELAJARAN BERBASIS DARING. JPMI: Jurnal Pembelajaran Matematika Inovatif, 3(6), 703-712. https://doi.org/10.22460/jpmi.v3i6.703-712

Puspita, S. (2018). Pengaruh Kedisiplinan Terhadap Hasil Belajar Mahasiswa Prodi Pendidikan Matematika. Jurnal LEMMA, 4(2), 75-80. 
https://doi.org/10.22202/j1.2017.v4i2.2730

Rusydayana, L. S., \& Supriyanto, A. (2013). Pengaruh kedisiplinan dan motivasi terhadap prestasi belajar mahasiswa. Seminar Nasional - Jurusan Administrasi Pendidikan Fakultas Ilmu Pendidikan Universitas Negeri Malang Arah Manajemen Pada Masa Dan Pasca Pandemi Covid-19, 140-148.

Sobri, M., Nursaptini, N., \& Novitasari, S. (2020). Mewujudkan Kemandirian Belajar Melalui Pembelajaran Berbasis Daring Diperguruan Tinggi Pada Era Industri 4.0. Jurnal Pendidikan Glasser, 4(1), 64. https://doi.org/10.32529/glasser.v4i1.373

Sudiana, R., Fatah, A., \& Khaerunnisa, E. (2017). Kemandirian Belajar Mahasiswa Melalui Pembelajaran Berbasis Virtual Class. Jurnal Penelitian Dan Pembelajaran Matematika, 10(1), 74-80. https://doi.org/10.30870/jppm.v10i1.1292

Supardi, S. (2014). PERAN KEDISIPLINAN BELAJAR DAN KECERDASAN MATEMATIS LOGIS DALAM PEMBELAJARAN MATEMATIKA. Jurnal Formatif, $4(2), 80-88$.

Tu'u, T. (2008). Peran Disiplin pada Perilaku dan Prestasi Siswa. PT Grasindo.

Wahyuni, R., \& Nurhayati. (2019). KEMANDIRIAN BELAJAR MAHASISWA MELALUI BLENDED LEARNING PADA MATA KULIAH MATEMATIKA EKONOMI. Jurnal Ilmiah Pendidikan Matematika AL-QALASADI, 3(2), 76-81.

Wirantasa, U. (2017). PENGARUH KEDISIPLINAN SISWA TERHADAP PRESTASI BELAJAR MATEMATIKA. Jurnal Formatif, 7(1), 83-95.

Yuliati, Y., \& Saputra, D. S. (2020). MEMBANGUN KEMANDIRIAN BELAJAR MAHASISWA MELALUI BLENDED LEARNING DI MASA PANDEMI COVID-19. Jurnal Elementaria Edukasia, 3(1), 142-149. 